\title{
Identification of target genes for a prolactin family paralog in mouse decidua
}

\author{
S M Khorshed Alam ${ }^{\dagger}$, Toshihiro Konno ${ }^{\ddagger}$ and Michael J Soares \\ Department of Pathology and Laboratory Medicine, Institute for Reproductive Health and Regenerative Medicine, \\ University of Kansas Medical Center, Kansas City, Kansas 66160, USA
}

Correspondence should be addressed to M J Soares; Email: msoares@kumc.edu

${ }^{\text {t}} \mathrm{S}$ M K Alam is now at Department of Biochemistry, Bagabandhu Sheikh Mujib Medical University, Dhaka, Bangladesh

${ }^{\ddagger} \mathrm{T}$ Konno is now at Department of Agro-Environmental Sciences, Faculty of Agriculture, University of the Ryukyus, 1 Senbaru, Nishihara, Okinawa 903-0213, Japan

\begin{abstract}
Prolactin family 8, subfamily a, member 2 (PRL8A2; also called decidual prolactin-related protein; dPRP) is a member of the expanded prolactin family. PRL8A2 is expressed in the uterine decidua and contributes to pregnancy-dependent adaptations to hypoxia. The purpose of this study was to identify gene targets for PRL8A2 action within the uteroplacental compartment. Affymetrix DNA microarray analysis was performed for RNA samples from WT and Prl8a2 null tissues. Validation of the DNA microarray was performed using quantitative RT-PCR. Nine genes were confirmed with decreased expression in Prl8a2 null tissues (e.g. Klk7, Rimklb, Arhgef6, Calm4, Sprr2h, Prl4a1, CCl27, Lipg, and Htra3). These include potential decidual, endothelial and trophoblast cell targets positively regulated by PRL8A2. A significant upregulation of Derl3, Herpud1, Creld2, Hsp90b1, Ddit3 and Hspa5 was identified in Prl8a2 null tissues, reflecting an increased endoplasmic reticulum (ER) stress response. ER stress genes were prominently expressed in the uterine decidua. We propose that PRL8A2 is a mediator of progesterone-dependent modulation of intrauterine responses to physiological stressors.

Reproduction (2015) $\mathbf{1 4 9}$ 625-632
\end{abstract}

\section{Introduction}

The mouse possesses an expanded prolactin (PRL) gene family that encodes hormones/cytokines (Wiemers et al. 2003, Soares et al. 2007). In some species the expansion was robust such as occurred in the mouse, rat, guinea pig and cow (Wiemers et al. 2003, Alam et al. 2006, 2010, Ushizawa \& Hashizume 2006), whereas evidence for an expansion in other species such as the human and dog is lacking (Cooke \& Liebhaber 1995, Lindblad-Toh et al. 2005). These hormones and cytokines are associated with pregnancy and are produced by the anterior pituitary, uterine decidua and/or trophoblast cells (Soares 2004). The biological activities of PRL are well described and include profound effects on the reproductive axis and lactation (Horseman et al. 1997, Bole-Feysot et al. 1998, Horseman \& Gregerson 2014); however, the actions of the remaining PRL family paralogs are less well appreciated. Roles for these PRL related proteins in regulating blood vessel and hematopoietic cell development have been demonstrated (Jackson et al. 1994, Lin \& Linzer 1999, Bittorf et al. 2000). Based on mouse mutagenesis experiments, the biological activities of at least some expanded PRL family paralogs include modulation of uteroplacental adaptations to physiological stressors (Ain et al. 2004, Alam et al. 2007, Soares et al. 2007). PRL also participates in homeostatic responses to stress (Dorshkind \& Horseman 2001).

Hemochorial placentation is associated with differentiation of uterine stromal cells into epithelial-like cells called decidual cells possessing extensive secretory capabilities and essential roles in the establishment and maintenance of pregnancy (Aplin 2000, Gellersen et al. 2007, Herington \& Bany 2009, Teklenburg et al. $2010 a, b)$. Decidual cells effectively create an environment within the uterus compatible with development of the placenta and fetus. Among the factors secreted by decidual cells are members of the PRL family (Orwig et al. 1997a, Jabbour \& Critchley 2001). Human decidual cells produce PRL, while the mouse and rat produce PRL and an additional three PRL family paralogs (Soares 2004, Soares et al. 2007).

Biological roles for decidual PRL family hormones/ cytokines are not well understood (Jabbour \& Critchley 2001). Among the decidual PRL family paralogs in the mouse and rat is a protein referred to as PRL family 8 , subfamily a, member 2 (PRL8A2; also referred to as decidual PRL-related protein dPRP; Roby et al. 1993). 
PRL8A2 is abundantly expressed in the uterine decidua (Roby et al. 1993, Gu et al. 1994, Rasmussen et al. 1996, 1997, Lin et al. 1997, Orwig et al. 1997a,b,c, Orwig \& Soares 1999, Bany \& Cross 2006, Alam et al. 2008), binds to heparin and although it is structurally similar to PRL it does not appear to signal through the PRL receptor (Rasmussen et al. 1996, Wang et al. 2000, Alam et al. 2008). PRL8A2 deficiency interferes with pregnancydependent adaptations to hypoxia resulting in pregnancy failure (Alam et al. 2007).

The purpose of this study was to identify candidate targets for PRL8A2 action within the uteroplacental compartment.

\section{Materials and methods}

\section{Animals and tissue preparation}

C57BL/6 mice were obtained from Jackson Laboratories (Bar Harbor, ME, USA). Mice were housed in an environmentally controlled facility, with lights on from 0600 to $2000 \mathrm{~h}$, and allowed free access to food and water. Timed matings of animals were conducted by placing females with fertile males. The day when a seminal plug was found in the vagina of female mice was designated as day 0.5 of pregnancy. Placentation sites, including uterus, decidual and placental tissues, were dissected from pregnant animals. Harvested tissues were snapfrozen in liquid nitrogen for RNA and protein analyses. For in situ hybridization analyses, tissues were frozen in dry icecooled heptane. All tissue samples were stored at $-80^{\circ} \mathrm{C}$ until used. Protocols for the preceding procedures have been described (Ain et al. 2006, Deb et al. 2006, Alam et al. 2007, 2008). The University of Kansas Medical Center Animal Care and Use Committee approved all procedures for handling and experimentation with rodents.

\section{DNA microarray}

WT and Prl8a2 null mice were mated and sacrificed on gestation day 7.5. Decidual-placental-embryonic tissues were dissected from implantation sites and homogenized. Total RNA was extracted using TRIzol reagent according to the manufacturer's protocol (Invitrogen). RNA extractions were pooled to form three groups of three for each group in nuclease-free water at a concentration of $1.0 \mu \mathrm{g} / \mu \mathrm{l}$. RNA samples were hybridized to the Affymetrix 430 2.0 DNA microarray chip using the GeneChip Hybridization Oven 640 (Affymetrix, Santa Clara, CA, USA). Washing and staining of the hybridized chips were conducted using the GeneChip Fluidics Station 450 (Affymetrix). Chips were scanned using the Affymetrix GeneChip Scanner 3000 (Affymetrix) with autoloader by the KUMC Biotechnology Support Facility. Hybridization signals were normalized with internal controls. Expression data sets were analyzed using the expression analysis software GeneSpring 7.0 and R Statistics Software (http://www.r-project.org/) with BioConductor Software (http://www.bioconductor.org/) packages. The RMA method from the BioConductor Software was used for background correction, normalization and summarization of the DNA microarray data. Statistical comparisons of expression values between two groups were determined with a moderated $t$-test. Pathway analysis was performed with AltAnalyze (http://altanalyze.org) and PathVisio (http://www.pathvisio.org).

\section{Quantitative RT-PCR}

cDNAs were synthesized with total RNA $(1 \mu \mathrm{g})$ from each sample using M-MLV reverse transcriptase (Invitrogen), diluted five times with water and subjected to quantitative RT-PCR (qRT-PCR) to quantify mRNA levels of the genes identified from the DNA microarray. Primers were designed using Primer Express 2.0 (Applied Biosystems). Primer sequences can be found in Table 1. Real-time PCR amplification of cDNAs was carried out in a reaction mixture $(10 \mu \mathrm{l})$ containing SYBR GREEN PCR Master Mix (Applied Biosystems) and primers (600 nM each). Amplification and fluorescence detection were carried out using the ABI Prism 7500 Real Time PCR System (Applied Biosystems). Cycling conditions included an initial hold step $\left(95^{\circ} \mathrm{C}\right.$ for $\left.10 \mathrm{~min}\right)$ and 40 cycles of a two-step PCR $\left(92{ }^{\circ} \mathrm{C}\right.$ for $15 \mathrm{~s}$, then $60^{\circ} \mathrm{C}$ for $1 \mathrm{~min}$ ), followed by a dissociation step $\left(95^{\circ} \mathrm{C}\right.$ for $15 \mathrm{~s}, 60^{\circ} \mathrm{C}$ for $15 \mathrm{~s}$, and then $95{ }^{\circ} \mathrm{C}$ for $15 \mathrm{~s}$ ). qRT-PCR for each query mRNA was validated, including

Table 1 Primer sequences for transcripts regulated by PRL8A2.

\begin{tabular}{|c|c|c|c|}
\hline Gene & $\begin{array}{l}\text { GenBank } \\
\text { accession no. }\end{array}$ & Forward primer & Reverse primer \\
\hline Rimklb & NM_027664 & TGAAGGCCAAATGTTGTGAA & TCTCСАCTGATCCGAAGACC \\
\hline Klk7 & NM_011872 & TCTGGCTCСТTTCССТGATA & GGTGCGAGCCTTCTTTACAT \\
\hline CCl27 & NM_001048179 & GACTGTCACCTCCAGGCTGT & СTTTTCCCTTGGCGTTCTAA \\
\hline Calm4 & NM_020036 & CAGAGATGTCTCACGGGTTT & GTTCCTCGACGCTGATATGG \\
\hline Prl4a1 & NM_011165 & GGAGACCATAGAGAAGATT & GCAAGAGTTCCAATTCAGA \\
\hline Lipg & NM_010720 & ССАААССАААААССТGСТТG & CGCCGGGAAGTAACAATAGA \\
\hline Htra3 & NM_001042615 & CCGATGTGGTGGAGAAGATT & ACTGGACAGCGGCACATT \\
\hline Sprr2h & NM_011474 & ACACTTGGTACTCAAGCTCT & AAGGCTGCTTGCACTGCT \\
\hline Arhgefb & NM_152801 & TCCССТAAGGCTATCAAAGGA & GGCATATTCTTTTTCAGTGTCC \\
\hline Derl3 & NM_024440 & GGGATTCGGCTTCTTTTTTCAA & CATGAAAACGAAGTCAGCCTT \\
\hline Herpud1 & NM_022331 & ССТСАGСАТССТTТАСТTСТ & СTCTGTCTGAACGGAAACCA \\
\hline Creld2 & NM_029720 & АCTGCACAGACGGCTTCTTC & CTTGGACCAGAGCAGGTCTT \\
\hline Hsp90b1 & NM_011631 & ATGGCACAGTGGAAGAGGAC & TGCGTTTAACCCATCCAACT \\
\hline Ddit3 & NM_007837 & САССТАТАТСТСАТССССА & GGATGTGCGTGTGACCTCT \\
\hline Hspa5 & NM_0011634 & TGCAGCAGGACATCAAGTTC & TTTCTTCTGGGGCAAATGTC \\
\hline $18 S$ & NR_003278 & GCAАTTATTCCССАТGAACG & GGССТСАСТАAАССАТССАА \\
\hline
\end{tabular}


determining amplification efficiencies and co-linearity of the query mRNAs and $18 \mathrm{~S}$ rRNA. The comparative CT method was used for relative quantification of the amount of $\mathrm{mRNA}$ for each sample normalized to $18 \mathrm{~S}$ RNA.

\section{In situ hybridization}

The localization of mRNAs within tissues was performed as described previously (Ain et al. 2003, Wiemers et al. 2003). Cryosections $(10 \mu \mathrm{m})$ of tissues were prepared and stored at $-80{ }^{\circ} \mathrm{C}$ until used. Plasmids containing cDNAs for mouse Rimklb, Derl3, Hspa5 and Hsp90b1 were used as templates to synthesize sense and antisense digoxigenin labeled riboprobes according to the manufacturer's instructions (Roche Molecular Biochemicals). Images were captured using a Leica MZFIII stereomicroscope (Leica Microsystems GmbH, Welzlar, Germany) or a Nikon Eclipse 55i microscope (Nikon Instruments, Inc., Melville, NY, USA), both equipped with Leica CCD cameras (Leica).

\section{Statistical analysis}

Statistical analyses were performed using the $\mathrm{R}$ Statistical Software (http://www.r-project.org). Statistical comparisons between two means were determined with Student's $t$-test or Welch's t-test, depending on the homogeneity of variances.

\section{Results}

Mice possessing null mutations at the Prl8a2 locus reproduce within the normal range but unlike WT mice do not effectively adapt when exposed to hypoxic conditions during pregnancy (Alam et al. 2007). This mutant mouse model was used as a tool to identify downstream actions of PRL8A2 signaling. We used DNA microarray analysis to examine the consequences of PRL8A2 deficiency on gene expression at gestation day 7.5. Gestation day 7.5 is associated with robust Prl8a2 expression and represents a pivotal time point in

Table 2 List of transcripts downregulated (greater than or equal to twofold) in implantation sites of the PRL8A2 deficient mouse.

\begin{tabular}{|c|c|c|c|c|}
\hline Gene name & Symbol & $\begin{array}{l}\text { GenBank } \\
\text { accession no. }\end{array}$ & Function & $\begin{array}{c}\text { Ratio } \\
\text { (null/WT) } \\
\end{array}$ \\
\hline Prolactin family 8 , subfamily A, member 2 & Prl8a2 & NM_010088 & Hormone/cytokine & 0.00 \\
\hline $\begin{array}{l}\text { Ribosomal modification protein rimK-like family } \\
\text { member B }\end{array}$ & Rimklb & AV2 $\overline{7} 1892$ & $\begin{array}{l}\text { ATP binding, amino acid ligase } \\
\text { activity, glutathione synthase } \\
\text { activity }\end{array}$ & 0.10 \\
\hline Kallikrein related peptidase 7 & $K I k 7$ & BB283507 & Trypsin-like serine protease & 0.22 \\
\hline Midline 1 & Mid1 & BG073178 & Microtubule associated & 0.25 \\
\hline Chemokine (C-C motif) ligand $27 \mathrm{a}$ & $\mathrm{CCl} 27 \mathrm{a}$ & NM_011336 & $\begin{array}{l}\text { Chemokine, leukocyte } \\
\text { recruitment }\end{array}$ & 0.28 \\
\hline Predicted gene, EG633640 & EG633640 & BG068672 & Unknown & 0.28 \\
\hline Proline rich 9 & A030004J04Rik & BB150166 & Unknown & 0.30 \\
\hline Orosomucoid 1 & Orm1 & BE628912 & $\begin{array}{l}\text { Transporter activity/ } \\
\text { immune-related }\end{array}$ & 0.30 \\
\hline Calmodulin 4 & Calm4 & NM_020036 & Calcium signaling & 0.35 \\
\hline Porcupine homolog & Porcn & $\mathrm{AB} 036749$ & Wnt signaling pathway & 0.35 \\
\hline Predicted gene 9780 & MGI:3710532 & Al508243 & Unknown & 0.36 \\
\hline Expressed sequence tag & - & AV271189 & Unknown & 0.40 \\
\hline Orosomucoid 2 & Orm2 & NM_011016 & $\begin{array}{l}\text { Transporter activity/ } \\
\text { immune-related }\end{array}$ & 0.40 \\
\hline Cellular retinoic acid binding protein & Crabp2 & ВC018397 & Retinoic acid transport & 0.40 \\
\hline Expressed sequence tag & - & BG083989 & Unknown & 0.40 \\
\hline Lipase, endothelial & Lipg & BC020991 & Lipid metabolism & 0.41 \\
\hline $\begin{array}{l}\text { A disintegrin-like and metalloproteinase with } \\
\text { thrombospondin type } 1 \text { motif, } 5\end{array}$ & Adamts5 & BB658835 & $\begin{array}{l}\text { Integrin-mediated signaling, } \\
\text { metalloproteinase }\end{array}$ & 0.41 \\
\hline Prolactin family 4 , subfamily A, member 1 & Prl4a1 & NM_011165 & Hormone/cytokine & 0.42 \\
\hline HtrA serine peptidase 3 & Htra3 & NM_030127 & Serine protease & 0.43 \\
\hline Expressed sequence tag & - & BM115786 & Unknown & 0.43 \\
\hline Small proline-rich protein $2 \mathrm{H}$ & Sprr2h & NM_011474 & Epithelial barrier & 0.43 \\
\hline Neuromedin U & Nmu & NM_019515 & Neuropeptide signaling & 0.43 \\
\hline PR domain containing 16 & Prdm16 & BB35 56786 & Transcription coregulator & 0.44 \\
\hline Endogenous retroviral sequence 3 & Erv3 & AK005451 & Unknown & 0.44 \\
\hline $\begin{array}{l}\text { Carcinoembryonic antigen-related cell adhesion } \\
\text { molecule } 9\end{array}$ & Ceacam9 & NM_011927 & Immune-related & 0.44 \\
\hline Expressed sequence tag & - & AU067772 & Unknown & 0.45 \\
\hline Expressed sequence tag & - & BB712583 & Unknown & 0.45 \\
\hline Guanylate cyclase activator $2 \mathrm{a}$ & Guca2a & NM_008190 & Activator of guanylate cyclase & 0.45 \\
\hline Calmodulin-like 3 & Calm/3 & NM_027416 & Calcium signaling & 0.46 \\
\hline Shisa homolog 3 & Shisa3 & AV277495 & FGF and WNT signaling & 0.46 \\
\hline Histidine ammonia lyase & Hal & L07645 & Histidine catabolism & 0.46 \\
\hline LRRN4 C-terminal like & Lrrn4cl & BB783125 & Unknown & 0.46 \\
\hline Predicted gene 9746 & D14Ertd449e & BG072279 & Unknown & 0.48 \\
\hline Rac/Cdc42 guanine nucleotide exchange factor 6 & Arhgef6 & NM_152801 & $\begin{array}{l}\text { Rho GTPase guanine nucleotide } \\
\text { exchange factor }\end{array}$ & 0.50 \\
\hline
\end{tabular}


decidual development and the establishment of the placenta. Probe sets for 57 transcripts exhibited a greater than or equal to twofold change in expression between Prl8a2 null and WT tissues. Thirty-four transcripts were significantly downregulated and 23 transcripts were significantly upregulated in the Prl8a2 null tissues $(P<0.05$, Tables 2 and 3$)$. The complete dataset has been deposited at the Gene Expression Omnibus (http://www.ncbi.nlm.nih.gov/geo/; accession number GSE60220). Pathway analyses of the transcriptome data were not informative.

Nine genes were confirmed with decreased expression in gestation day 7.5 Prl8a2 null implantation sites (e.g. Klk7, Rimklb, Ccl27, Calm4, Prl4a1, Lipg, Sprr2h, Htra3, Arhgef6; Table 2, Fig. 1). These include potential decidual, endothelial and trophoblast cell targets positively regulated by PRL8A2. Rmklb transcripts were localized to a subset of cells within the antimesometrial decidual compartment of the gestation day 7.5 implantation site (Fig. 2).

Six genes were confirmed with increased expression in gestation day 7.5 Prl8a2 null implantation sites (Derl3,
Herpud1, Creld2, Hsp90b1, Ddit3, and Hspa5; Table 3, Fig. 3). Each of these transcripts encodes proteins that participate in the endoplasmic reticulum (ER) stress response. Derl3, Hspa5, and Hsp90b1 transcripts were localized to the anti-mesometrial decidual compartment and were dramatically upregulated in the Prl8a2 null mouse (Fig. 4).

\section{Discussion}

The uterine deciduum is a transitory tissue with the responsibilities of modulating hemochorial placentation. A PRL-related cytokine, PRL8A2, is expressed in a temporally- and spatially-precise pattern within the uterine deciduum during the establishment of pregnancy. PRL8A2 facilitates pregnancy-associated uterine adaptations to physiological stressors (Alam et al. 2007). In this report, we identified potential targets of PRL8A2 action and determined that PRL8A2 acts in a pathway that restrains activation of decidual cell ER stress.

The ER stress response is a cellular process facilitating adaptations to harmful conditions, including cellular

Table 3 List of transcripts upregulated (greater than or equal to twofold) in implantation sites of the PRL8A2 deficient mouse.

\begin{tabular}{|c|c|c|c|c|}
\hline Gene name & Symbol & $\begin{array}{l}\text { GenBank } \\
\text { accession no. }\end{array}$ & Function & $\begin{array}{c}\text { Ratio } \\
\text { (null/WT) }\end{array}$ \\
\hline Platelet-derived growth factor receptor-like & Pdgfrl & Ak004179 & Similarity to ligand binding domain of Pdgfr & 11.48 \\
\hline Der1-like domain family, member 3 & Derl3 & AK007348 & Endoplasmic reticulum stress response & 6.29 \\
\hline Expressed sequence tag & - & AK007420 & Unknown & 4.65 \\
\hline $\begin{array}{l}\text { SWI/SNF related, matrix associated, actin } \\
\text { dependent regulator of chromatin, } \\
\text { subfamily b, member } 1\end{array}$ & Smarcb1 & BB820473 & Chromatin remodeling & 3.84 \\
\hline Nicotinamide nucleotide transhydrogenase & Nnt & BB205930 & $\begin{array}{l}\text { Mitochondrial enzyme, production of } \\
\text { NADPH }\end{array}$ & 3.20 \\
\hline CDC14 cell division cycle 14 homolog B & $C d c 14 b$ & AK013228 & $\begin{array}{l}\text { Protein tyrosine phosphatase, cell cycle } \\
\text { control }\end{array}$ & 3.10 \\
\hline $\begin{array}{l}\text { Homocysteine-inducible, endoplasmic reticu- } \\
\text { lum stress-inducible, ubiquitin-like domain } \\
\text { member } 1\end{array}$ & Herpud1 & NM_022331 & Endoplasmic reticulum stress response & 3.00 \\
\hline EF-hand calcium binding domain 7 & Efcab7 & BC020077 & Calcium binding & 2.91 \\
\hline Expressed sequence tag & - & BB629079 & Unknown & 2.84 \\
\hline Cysteine-rich with EGF-like domains 2 & Creld2 & AK017880 & $\begin{array}{l}\text { Endoplasmic reticulum stress response/ } \\
\text { calcium binding }\end{array}$ & 2.75 \\
\hline Expressed sequence tag & - & AK007420 & Unknown & 2.69 \\
\hline Rab9 effector protein with kelch motifs & Rabepk & AA217054 & $\begin{array}{l}\text { Facilitates transport of mannose } \\
6 \text {-phosphate receptor }\end{array}$ & 2.60 \\
\hline Arrestin domain containing 3 & Arrdc3 & AW556597 & $\begin{array}{l}\text { Associated with G protein-coupled } \\
\text { receptor signaling }\end{array}$ & 2.44 \\
\hline$\gamma$-aminobutyric acid A receptor, subunit $\alpha 2$ & Gabra2 & BB339336 & $\begin{array}{l}\text { GABA-A receptor, ligand-gated chloride } \\
\text { channel }\end{array}$ & 2.39 \\
\hline Immunoglobulin $\kappa$ constant & $\operatorname{lgk} c$ & AV057155 & Light chain of antibodies & 2.38 \\
\hline Hemochromatosis & Hfe & AJ306425 & Iron transport & 2.38 \\
\hline Predicted gene, EG665955 & EG665955 & BF580235 & Unknown & 2.23 \\
\hline $\begin{array}{l}\text { DNA segment, Chr 13, ERATO Doi 666, } \\
\text { expressed }\end{array}$ & D13Ertd666e & BG070282 & Unknown & 2.17 \\
\hline DNA-damage inducible transcript 3 & Ddit3 & NM_007837 & Endoplasmic reticulum stress response & 2.13 \\
\hline Heat shock protein 5 & Hspa5 & AJ002387 & Endoplasmic reticulum stress response & 2.07 \\
\hline Uroplakin 1B & Upk1b & BB427704 & $\begin{array}{l}\text { Member of the tetraspanin family, signal } \\
\text { transduction }\end{array}$ & 2.06 \\
\hline Expressed sequence tag & - $\quad$ & BG862223 & Unknown & 2.04 \\
\hline Heat shock protein $90, \beta$, member 1 & Hsp90b1 & NM_011631 & Endoplasmic reticulum stress response & 2.00 \\
\hline
\end{tabular}




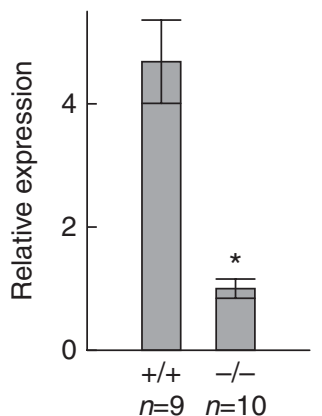

KIk7

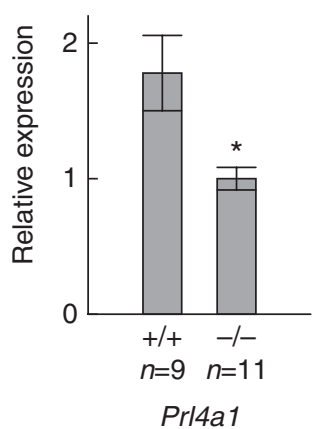

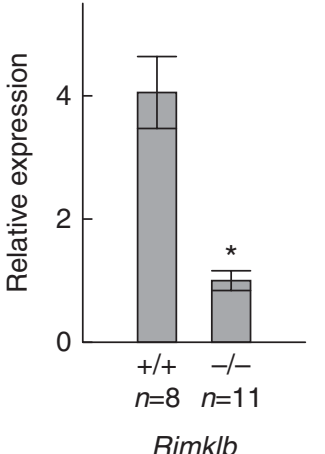

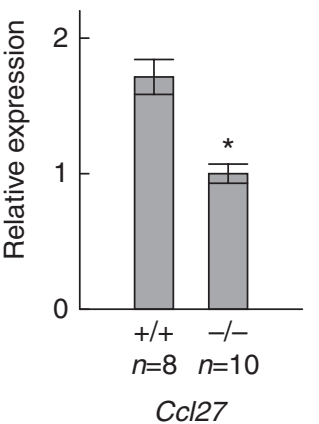

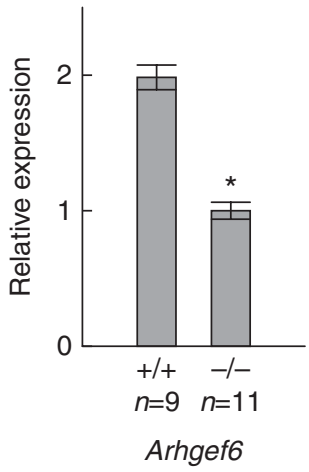
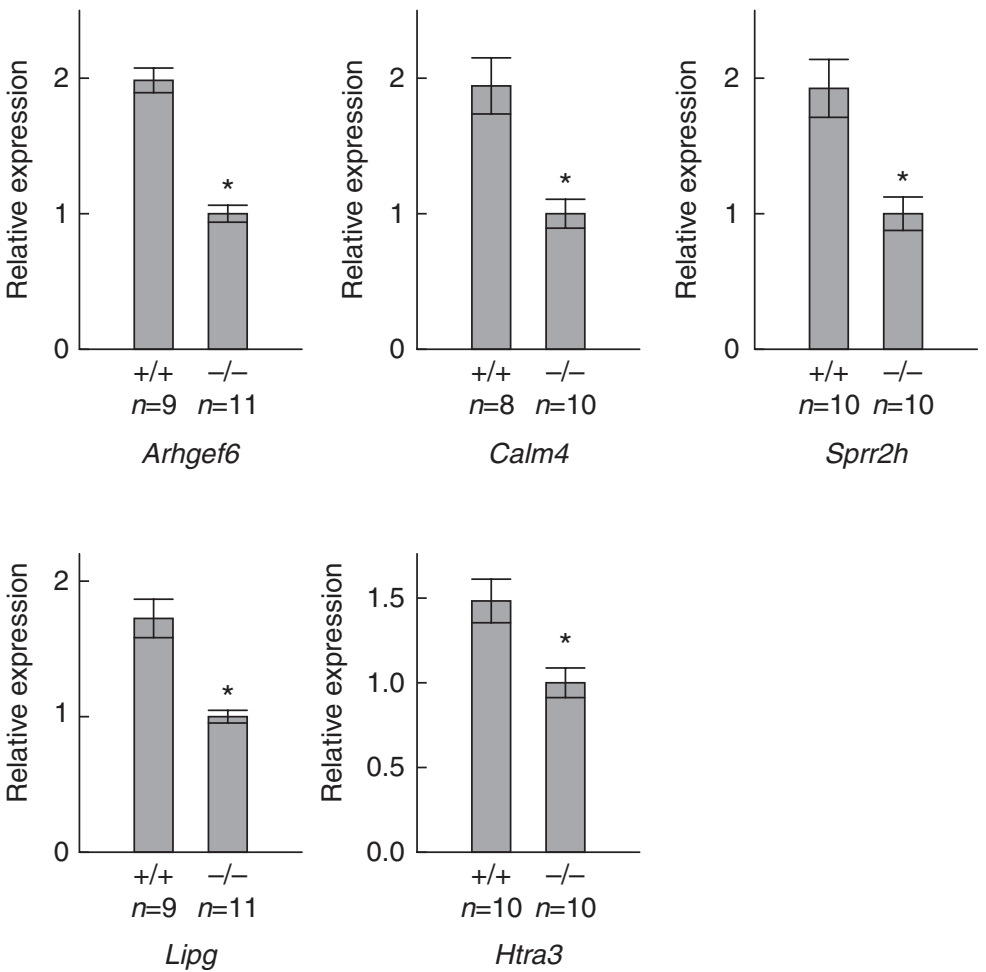

Figure 1 Validation of expression profiles of genes downregulated in Prl8a2 null conceptus tissues. Total RNA samples from WT (+/+) and Prl8a2 $(-/-)$ null gestation day 7.5 implantation sites were subjected to quantitative RT-PCR (SYBR Green, $\Delta \Delta C \mathrm{Ct}$ method) with transcript specific primer sets. Reactions were performed in duplicate. $18 \mathrm{~S}$ rRNA served as an internal control. Please note the significant downregulation genes in the Prl8a2 null tissues. Asterisks denote significant differences between WT and Prl8a2 null samples, $P<0.05$.

damage, and if severe or prolonged leads to cell death (Xu et al. 2005, Yoshida 2007, Zhang \& Kaufman 2008). Implantation of the embryo within the uterus elicits many of the hallmarks of an inflammatory response (Finn 1986, Mor et al. 2011). Inflammation leads to cellular injury and activation of ER stress (Zhang \& Kaufman 2008). An assortment of pregnancy-related disorders, including early pregnancy loss, preeclampsia and intrauterine growth restriction, are associated with increased decidual cell ER stress responses (Lian et al. 2011, Liu et al. 2011, Loset et al. 2011, Gao et al. 2012). Pregnancy related disease occurs when the harmful inflammatory stimuli are excessive or the decidual cell adaptations are inadequate. Consequently, during the establishment of a successful pregnancy mechanisms must exist to thwart excessive or prolonged ER stress responses, which could compromise embryo survival.

The PRL family is part of a conserved decidual cell adaptation regulatory pathway. PRL and a subgroup of PRL related genes are expressed in decidua cells of the rat, mouse, and human (Orwig et al. 1997a, Telgmann \& Gellersen 1998). PRL has a decidua-protective role in the rat and mouse. It inhibits the expression of decidual genes that interfere with the maintenance of pregnancy (Tessier et al. 2001, Bao et al. 2007). Complementary observations are apparent in the human. PRL is produced by decidua and its production is impaired in decidua from patients with recurrent pregnancy loss (Salker et al. 2010, Teklenburg et al. 2010a,b) and correlates with failures in optimal embryo recognition (Brosens \& Gellersen 2010, Weimar et al. 2012). PRL8A2, a PRLrelated protein, is abundantly expressed in decidua of
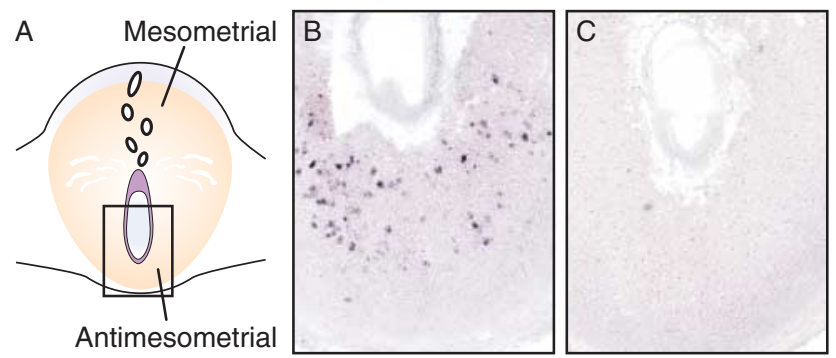

Figure 2 In situ detection of Rimklb mRNA within implantation sites on gestation day 7.5. (A) Schematic representation of implantation sites from day 7.5 of gestation. The black box indicates the region of images shown in (B) and (C). Gestation day 7.5 implantation sites of both WT $(+/+, B)$ and Prl8a2 null $(-/-$, C) mice were subjected to in situ hybridization with a Rimklb specific antisense RNA probe. Please note the significant downregulation of Rimklb mRNA in the antimesometrial compartments of Prl8a2 null tissues. 
the mouse and rat, especially within anti-mesometrial decidua (Orwig et al. 1997a,b,c, Rasmussen et al. 1997). In the absence of PRL8A2, transcripts associated with ER stress are significantly upregulated in the anti-mesometrial decidua. Insights into the mechanism of PRL8A2 action are modest. PRL8A2 is a secreted heparin-binding cytokine (Rasmussen et al. 1996, Wang et al. 2000, Alam et al. 2008). Although PRL8A2 is structurally related to $\mathrm{PRL}$, it does not bind the PRL receptor (Rasmussen et al. 1996). Collectively, the results suggest that the deciduaprotective functions associated with PRL may extend to other members of the PRL family, including PRL8A2.

DDIT3 is a component of the ER stress response targeted by PRL8A2 and may represent a critical modulator of the integrity of decidual cells. DDIT3 is also known as CCAAT/enhancer-binding protein (C/EBP) homologous protein (CHOP) and is a negative modulator of C/EBP transcriptional regulation (Ron \& Habener 1992, Tang \& Lane 2000). C/EBP $\beta$ is a key transcriptional mediator of the actions of progesterone on decidual cell differentiation (Bagchi et al. 2006, Mantena et al. 2006, Wang et al. 2010, Ramathal et al. 2011). Uterine stromal cells of C/EBP $\beta$ null female mice fail to undergo decidualization and are unresponsive to the actions of progesterone (Bagchi et al. 2006, Mantena et al. 2006). Progesterone signaling and C/EBP $\beta$ also synergize in the differentiation of primate endometrial stromal cells to decidual cells (Pohnke et al. 1999,
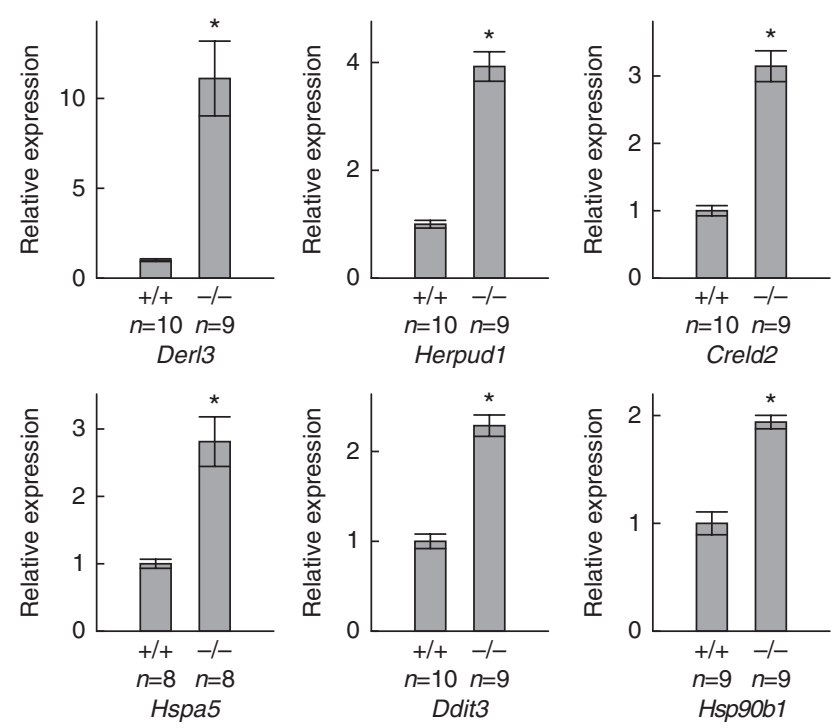

Figure 3 Validation of expression profiles of genes upregulated in Prl8a2 null conceptus tissues. Total RNA samples from WT $(+/+)$ and Prl8a2 (-/-) null gestation day 7.5 implantation sites were subjected to quantitative RT-PCR (SYBR Green, $\Delta \Delta C \mathrm{t}$ method) with transcript specific primer sets. Reactions were performed in duplicate. $18 \mathrm{~S}$ rRNA served as an internal control. Please note the significant upregulation genes in the Prl8a2 null tissues. Asterisks denote significant differences between WT and Prl8a2 null samples, $P<0.05$.

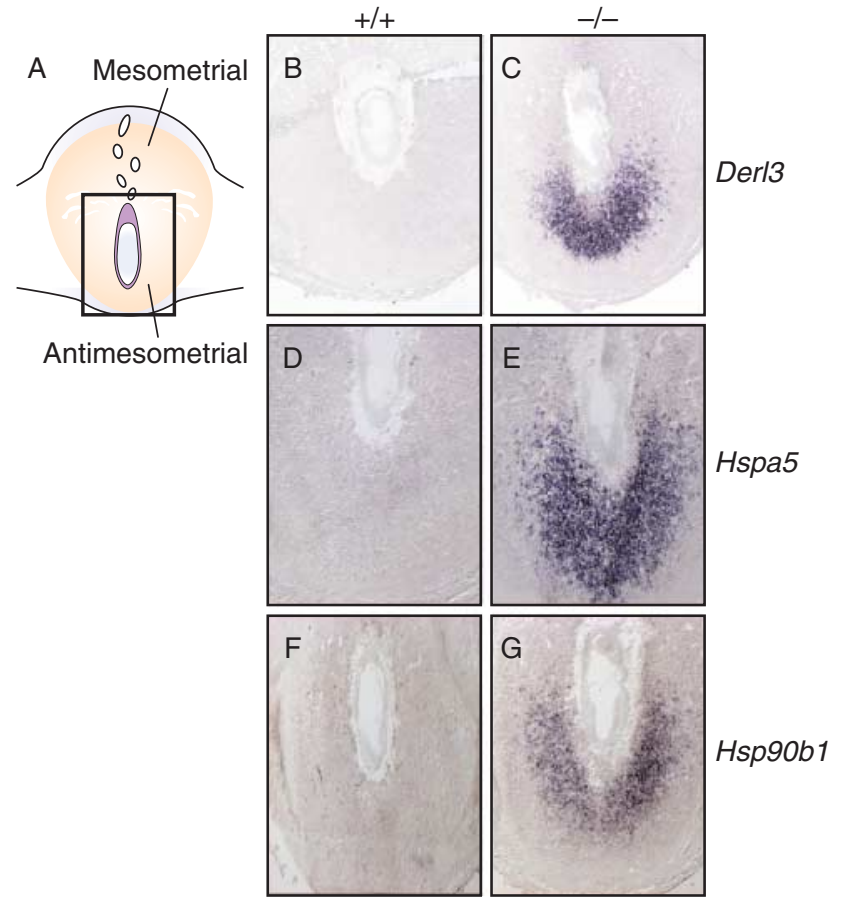

Figure 4 In situ detection of Derl3, Hspa5, Hsp90b1 mRNA within implantation sites on gestation day 7.5. (A) Schematic representation of implantation sites from day 7.5 of gestation. The black box indicates the region of images shown in (B-C). Serial cryosections from gestation day 7.5 implantation sites of both WT $(+/+, B, D$ and F) and Prl8a2 null $(-/-, C, E$ and G) mice were subjected to in situ hybridization with a gene specific antisense RNA probes. Please note the significant upregulation of Derl3, Hspa5, and Hsp90b1 in the anti-mesometrial compartment of the Prl8a2 null uterus.

Christian et al. 2002a,b, Kannan et al. 2010). This leads us to speculate that by restraining DDIT3 expression, PRL8A2 effectively facilitates the actions of progesterone and $\mathrm{C} / \mathrm{EBP} \beta$ on decidual cell development and integrity.

\section{Declaration of interest}

The authors declare that there is no conflict of interest that could be perceived as prejudicing the impartiality of the research reported.

\section{Funding}

This work was supported in part by research grants from the National Institutes of Health (HD020676, HD055523, HD066406).

\section{References}

Ain R, Canham LN \& Soares MJ 2003 Gestation stage-dependent intrauterine trophoblast cell invasion in the rat and mouse: novel endocrine phenotype and regulation. Developmental Biology 260 176-190. (doi:10.1016/S0012-1606(03)00210-0) 
Ain R, Dai G, Dunmore JH, Godwin AR \& Soares MJ 2004 A prolactin family paralog regulates reproductive adaptations to a physiological stressor. PNAS 101 16543-16548. (doi:10.1073/pnas.0406185101)

Ain R, Konno T, Canham LN \& Soares MJ 2006 Phenotypic analysis of the rat placenta. Methods in Molecular Medicine 121 295-313. (doi:10.1385/1-59259-983-4:293)

Alam SMK, Ain R, Konno T, Ho-Chen JK \& Soares MJ 2006 The rat prolactin gene family locus: species-specific gene family expansion. Mammalian Genome 17 858-877. (doi:10.1007/s00335-006-0010-1)

Alam SMK, Konno T, Dai G, Lu L, Wang D, Dunmore JH, Godwin AR \& Soares MJ 2007 A uterine decidual cell cytokine ensures pregnancydependent adaptations to a physiological stressor. Development 134 407-415. (doi:10.1242/dev.02743)

Alam SMK, Konno T, Sahgal N, Lu L \& Soares MJ 2008 Decidual cells produce a heparin-binding prolactin family cytokine with putative intrauterine regulatory actions. Journal of Biological Chemistry 283 18957-18968. (doi:10.1074/jbc.M801826200)

Alam SM, Konno T, Rumi MA, Dong Y, Weiner CP \& Soares MJ 2010 Prolactin family of the guinea pig, Cavia porcellus. Endocrinology 151 3918-3928. (doi:10.1210/en.2010-0239)

Aplin J 2000 Maternal influences on placental development. Seminars in Cell \& Developmental Biology 11 115-125. (doi:10.1006/scdb.2000. 0157)

Bagchi MK, Mantena SR, Kannan A \& Bagchi IC 2006 Control of uterine cell proliferation and differentiation by C/EBP $\beta$. Cell Cycle 5 922-925. (doi:10.4161/cc.5.9.2712)

Bany BM \& Cross JC 2006 Post-implantation mouse conceptuses produce paracrine signals that regulate the uterine endometrium undergoing decidualization. Developmental Biology 294 445-456. (doi:10.1016/ j.ydbio.2006.03.006)

Bao L, Tessier C, Prigent-Tessier A, Li F, Buzzio OL, Callegari EA, Horseman ND \& Gibori G 2007 Decidual prolactin silences the expression of genes detrimental to pregnancy. Endocrinology $\mathbf{1 4 8}$ 2326-2334. (doi:10.1210/en.2006-1643)

Bittorf T, Jaster R, Soares MJ, Seiler J, Brock J, Friese K \& Müller H 2000 Induction of erythroid proliferation and differentiation by a trophoblastspecific cytokine involves activation of the JAK/STAT pathway. Journal of Molecular Endocrinology 25 253-262. (doi:10.1677/jme.0.0250253)

Bole-Feysot C, Goffin V, Edery M, Binart N \& Kelly PA 1998 Prolactin (PRL) and its receptor: actions, signal transduction pathways and phenotypes observed in PRL receptor knockout mice. Endocrine Reviews 19 225-268. (doi:10.1210/edrv.19.3.0334)

Brosens JJ \& Gellersen B 2010 Something new about early pregnancy: decidual biosensoring and natural embryo selection. Ultrasound in Obstetrics \& Gynecology 36 1-5. (doi:10.1002/uog.7714)

Christian M, Pohnke Y, Kempf R, Gellersen B \& Brosens JJ 2002a Functional association of PR and CCAAT/enhancer-binding protein $\beta$ isoforms: promoter-dependent cooperation between PR-B and liver-enriched inhibitory protein, or liver-enriched activatory protein and PR-A in human endometrial stromal cells. Molecular Endocrinology 16 141-154. (doi:10.1210/mend.16.1.0763)

Christian M, Zhang X, Schneider-Merck T, Unterman TG, Gellersen B, White JO \& Brosens JJ 2002b Cyclic AMP-induced forkhead transcription factor, FKHR, cooperates with CCAAT/enhancer-binding protein $\beta$ in differentiating human endometrial stromal cells. Journal of Biological Chemistry 277 20825-20832. (doi:10.1074/jbc.M201018200)

Cooke NE \& Liebhaber SA 1995 Molecular biology of the growth hormoneprolactin gene system. Vitamins and Hormones 50 385-459.

Deb K, Reese J \& Paria BC 2006 Methodologies to study implantation in mice. Methods in Molecular Medicine 121 9-34. (doi:10.1385/1-59259983-4:007)

Dorshkind K \& Horseman ND 2001 Anterior pituitary hormones, stress, and immune system homeostasis. Bioessays 23 288-294. (doi:10.1002/ 1521-1878(200103)23:3<288::AID-BIES1039>3.0.CO;2-P)

Finn CA 1986 Implantation, menstruation and inflammation. Biological Reviews of the Cambridge Philosophical Society 61 313-328. (doi:10.1111/j.1469-185X.1986.tb00657.x)

Gao H-J, Zhu Y-M, He W-H, Liu A-X, Dong M-Y, Jin M, Sheng J-Z \& Huang H-F 2012 Endoplasmic reticulum stress induced by oxidative stress in decidual cells: a possible mechanism of early pregnancy loss. Molecular Biology Reports 39 9179-9186. (doi:10.1007/s11033-0121790-x)
Gellersen B, Brosens IA \& Brosens JJ 2007 Decidualization of the human endometrium: mechanisms, functions, and clinical perspectives. Seminars in Reproductive Medicine 25 445-453. (doi:10.1055/s-2007991042)

Gu Y, Soares MJ, Srivastava RK \& Gibori G 1994 Expression of decidual prolactin-related protein in the rat decidua. Endocrinology 135 1422-1427. (doi:10.1210/endo.135.4.7925104)

Herington JL \& Bany BM 2009 Do molecular signals from the conceptus influence endometrium decidualization in rodents? Journal of Experimental Zoology. Part B, Molecular and Developmental Evolution 312 797-816. (doi:10.1002/jez.b.21308)

Horseman ND \& Gregerson KA 2014 Prolactin actions. Journal of Molecular Endocrinology 52 R95-R106. (doi:10.1530/JME-13-0220)

Horseman ND, Zhao W, Montecino-Rodriguez E, Tanaka M, Nakashima K, Engle SJ, Smith F, Markoff E \& Dorshkind K 1997 Defective mammopoiesis, but normal hematopoiesis, in mice with a targeted disruption of the prolactin gene. EMBO Journal 16 6926-6935. (doi:10. 1093/emboj/16.23.6926)

Jabbour HN \& Critchley HOD 2001 Potential roles of decidual prolactin in early pregnancy. Reproduction 121 197-205. (doi:10.1530/rep.0. 1210197)

Jackson D, Volpert OV, Bouck N \& Linzer DI 1994 Stimulation and inhibition of angiogenesis by placental proliferin and proliferin-related protein. Science 266 1581-1584. (doi:10.1126/science.7527157)

Kannan A, Fazleabas AT, Bagchi IC \& Bagchi MK 2010 The transcription factor $\mathrm{C} / \mathrm{EBP} \beta$ is a marker of uterine receptivity and expressed at the implantation site in the primate. Reproductive Sciences 17 434-443. (doi:10.1177/1933719110361384)

Lian IA, Loset M, Mundal SB, Fenstad MH, Johnson MP, Eide IP, Bjorge L, Freed KA, Moses EK \& Austgulen R 2011 Increased endoplasmic reticulum stress in decidual tissue from pregnancies complicated by fetal growth restriction with and without pre-eclampsia. Placenta 32 823-829. (doi:10.1016/j.placenta.2011.08.005)

Lin J \& Linzer DI 1999 Induction of megakaryocyte differentiation by a novel pregnancy-specific hormone. Journal of Biological Chemistry $\mathbf{2 7 4}$ 21485-21489. (doi:10.1074/jbc.274.30.21485)

Lin J, Poole J \& Linzer DIH 1997 Three new members of the mouse prolactin/growth hormone family are homologous to proteins expressed in the rat. Endocrinology 138 5541-5549. (doi:10.1210/endo.138. 12.5626)

Lindblad-Toh K, Wade CM, Mikkelsen TS, Karlsson EK, Jaffe DB, Kamal M, Clamp M, Chang JL, Kulbokas EJ III, Zody MC et al. 2005 Genome sequence, comparative analysis and haplotype structure of the domestic dog. Nature 438 803-819. (doi:10.1038/nature04338)

Liu A-X, He W-H, Yin L-J, Lv P-P, Zhang Y, Sheng J-Z, Leung PCK \& Huang H-F 2011 Sustained endoplasmic stress as a cofactor of oxidative stress in decidual cells from patients with early pregnancy loss. Journal of Clinical Endocrinology and Metabolism 96 E493-E497. (doi:10.1210/jc. 2010-2192)

Loset M, Mundal SB, Johnson MP, Fenstad MH, Freed KA, Lian IA, Eide IP, Bjorge L, Blangero J, Moses EK et al. 2011 A transcriptional profile of the decidua in preeclampsia. American Journal of Obstetrics and Gynecology 204 e1-e27. (doi:10.1016/j.ajog.2010.08.043)

Mantena SR, Kannan A, Cheon YP, Li Q, Johnson PF, Bagchi IC \& Bagchi MK 2006 C/EBP $\beta$ is a critical mediator of steroid hormoneregulated cell proliferation and differentiation in the uterine epithelium and stroma. PNAS 103 1870-1875. (doi:10.1073/pnas.0507261103)

Mor G, Cardenas I, Abrahams V \& Guller S 2011 Inflammation and pregnancy: the role of the immune system at the implantation site. Annals of the New York Academy of Sciences 1221 80-87. (doi:10.1111/ j.1749-6632.2010.05938.x)

Orwig KE \& Soares MJ 1999 Transcriptional activation of the decidual/ trophoblast prolactin-related protein gene. Endocrinology $\mathbf{1 4 0}$ 4032-4039. (doi:10.1210/endo.140.9.6954)

Orwig KE, Rasmussen CA \& Soares MJ 1997a Decidual signals in the establishment of pregnancy: the prolactin family. Trophoblast Research 10 329-343.

Orwig KE, Dai G, Rasmussen CA \& Soares MJ $1997 b$ Decidual/trophoblast prolactin related protein: characterization of gene structure and cellspecific expression. Endocrinology 138 2491-2500. (doi:10.1210/endo. 138.6.5155) 
Orwig KE, Ishimura R, Müller H, Liu B \& Soares MJ 1997C Identification and characterization of a mouse homolog for decidual/trophoblast prolactin-related protein. Endocrinology 139 5511-5517. (doi:10.1210/ endo.138.12.5628)

Pohnke Y, Kempf R \& Gellersen B 1999 CCAAT/enhancer-binding proteins are mediators in the protein kinase A-dependent activation of the decidual prolactin promoter. Journal of Biological Chemistry 274 24808-24818. (doi:10.1074/jbc.274.35.24808)

Ramathal C, Wang W, Hunt E, Bagchi IC \& Bagchi MK 2011 Transcription factor CCAAT enhancer-binding protein $\beta(\mathrm{C} / \mathrm{EBP} \beta)$ regulates the formation of a unique extracellular matrix that controls uterine stromal differentiation and embryo implantation. Journal of Biological Chemistry 286 19860-19871. (doi:10.1074/jbc.M110.191759)

Rasmussen CA, Hashizume K, Orwig KE, Xu L \& Soares MJ 1996 Decidual prolactin-related protein: heterologous expression and characterization. Endocrinology 137 5558-5566. (doi:10.1210/endo.137.12.8940384)

Rasmussen CA, Orwig KE, Vellucci S \& Soares MJ 1997 Dual expression of prolactin-related protein in decidua and trophoblast tissues during pregnancy. Biology of Reproduction 55 647-654. (doi:10.1095/biolreprod56.3.647)

Roby KF, Deb S, Gibori G, Szpirer C, Levan G, Kwok SCM \& Soares MJ 1993 Decidual prolactin related protein: identification, molecular cloning and characterization. Journal of Biological Chemistry 268 3136-3142.

Ron D \& Habener JF 1992 CHOP, a novel developmentally regulated nuclear protein that dimerizes with transcription factors C/EBP and LAP and functions as a dominant-negative inhibitor of gene transcription. Genes and Development 6 439-453. (doi:10.1101/gad.6.3.439)

Salker M, Teklenburg G, Molokhia M, Lavery S, Trew G, Aojanepong T, Mardon HJ, Lokugamage AU, Rai R, Landles C et al. 2010 Natural selection of human embryos: impaired decidualization of endometrium disables embryo-maternal interactions and causes recurrent pregnancy loss. PLoS ONE 5 e10287. (doi:10.1371/journal.pone.0010287)

Soares MJ 2004 The prolactin and growth hormone families: pregnancy-specific hormones/cytokines at the maternal-fetal interface. Reproductive Biology and Endocrinology 2 51. (doi:10.1186/14777827-2-51)

Soares MJ, Konno T \& Alam SMK 2007 The prolactin family: effectors of pregnancy-specific adaptations. Trends in Endocrinology and Metabolism 18 114-121. (doi:10.1016/j.tem.2007.02.005)

Tang Q-Q \& Lane MD 2000 Role of C/EBP homologous protein (CHOP-10) in the programmed activation of CCAAT/enhancer-binding protein- $\beta$ during adipogenesis. PNAS 97 12446-12450. (doi:10.1073/pnas. 220425597)

Teklenburg G, Salker M, Heijnen C, Macklon NS \& Brosens JJ 2010a The molecular basis of recurrent pregnancy loss: impaired natural embryo selection. Molecular Human Reproduction 16 886-895. (doi:10.1093/ molehr/gaq079)
Teklenburg G, Salker M, Molokhia M, Lavery S, Trew G, Aojanepong T, Mardon HJ, Lokugamage AU, Rai R, Landles C et al. 2010b Natural selection of human embryos: decidualizing endometrial stromals cells serve as sensors of embryo quality upon implantation. PLOS ONE 5 e10258. (doi:10.1371/journal.pone.0010258)

Telgmann R \& Gellersen B 1998 Marker genes of decidualization: activation of the decidual prolactin gene. Human Reproduction Update 4 472-479. (doi:10.1093/humupd/4.5.472)

Tessier C, Prigent-Tessier A, Ferguson-Gottschall S, Gu Y \& Gibori G 2001 $\mathrm{PRL}$ antiapoptotic effect in the rat decidua involves the PI3K/protein kinase B-mediated inhibition of caspase-3 activity. Endocrinology 142 4086-4094. (doi:10.1210/endo.142.9.8381)

Ushizawa K \& Hashizume K 2006 Biology of the prolactin family in bovine placenta, II. Bovine prolactin-related proteins: their expression, structure, and proposed roles. Animal Science Journal 77 18-27. (doi:10.1111/j.1740-0929.2006.00315.x)

Wang D, Ishimura R, Walia DS, Müller H, Dai G, Hunt JS, Lee NA, Lee JJ \& Soares MJ 2000 Eosinophils are cellular targets of the novel uteroplacental heparin-binding cytokine, decidual/trophoblast prolactinrelated protein. Journal of Endocrinology 167 15-29. (doi:10.1677/joe. $0.1670015)$

Wang W, Li Q, Bagchi IC \& Bagchi MK 2010 The CCAAT/enhancer binding protein $\beta$ is a critical regulator of steroid-induced mitotic expansion of uterine stromal cells during decidualization. Endocrinology 151 3929-3940. (doi:10.1210/en.2009-1437)

Weimar CHE, Kavelaars A, Brosens J, Gellersen B, de VreedenElbertse JMT, Heijnen CJ \& Macklon NS 2012 Endometrial stromal cells of women with recurrent miscarriage fail to discriminate between high- and low-quality human embryos. PLOS ONE 7 e41424. (doi:10. 1371/journal.pone.0041424)

Wiemers DO, Shao L-J, Ain R, Dai G \& Soares MJ 2003 The mouse prolactin gene family locus. Endocrinology 144 313-325. (doi:10.1210/ en.2002-220724)

Xu C, Bailly-Maitre B \& Reed JC 2005 Endoplasmic reticulum stress: cell life and death decisions. Journal of Clinical Investigation 115 2656-2664. (doi:10.1172/JCl26373)

Yoshida H 2007 ER stress and diseases. FEBS Journal 274 630-658. (doi:10.1111/j.1742-4658.2007.05639.x)

Zhang K \& Kaufman RJ 2008 From endoplasmic-reticulum stress to the inflammatory response. Nature 454 455-462. (doi:10.1038/nature07203)

Received 8 August 2014

First decision 5 September 2014

Revised manuscript received 10 March 2015

Accepted 27 March 2015 